\title{
Never been such a clear need for science to protect the planet
}

\author{
Wilson Medeiros Pereira ${ }^{1}$ \\ Renato Assis Machado 2 \\ Daniella Reis Barbosa Martelli ${ }^{3}$ \\ Mário Sérgio Oliveira Swerts ${ }^{4}$ \\ Hercílio Martelli Júnior 5
}

\section{INTRODUCTION}

On June 18, 2015, Pope Francis issued the encyclical Laudato Si: On care for our common home. The letter has been widely praised for supporting the science on climate change. But it goes much further than many expected in documenting the phenomenal changes that our planet is undergoing, beyond climate. The urgent challenge to protect our common home includes a concern to bring the whole human family together to seek a sustainable and integral development, for we know that things can change

1 Health Science Postgraduate Program, State University of Montes Claros (Unimontes), Montes Claros, Minas Gerais, Brazil. $\triangle$ wmpmoc@gmail.com .iD https://orcid.org/0000-0002-2380-3098 .

2Department of Oral Diagnosis, School of Dentistry, University of Campinas (FOP/UNICAMP), Piracicaba, São Paulo, Brazil. Hospital for Rehabilitation of Craniofacial Anomalies, University of São Paulo (HRAC/USP), Bauru, São Paulo, Brazil. $₫$ renatoassismachado@yahoo.com.br .iD https://orcid.org/00000002-1697-3662.

3Primary Care Postgraduate Program, State University of Montes Claros (Unimontes), Montes Claros, Minas Gerais, Brazil. $₫$ daniellareismartelli@yahoo.com.br.(D) https://orcid.org/0000-0002-7497-6052.

4Center for Rehabilitation of Craniofacial Anomalies, University of Alfenas, Minas Gerais, Brazil. $\square$ mariosergio.swerts@gmail.com (i) https://orcid.org/0000-0003-1867-7880.

5Health Science Postgraduate Program, State University of Montes Claros (Unimontes), Montes Claros, Minas Gerais, Brazil. Center for Rehabilitation of Craniofacial Anomalies, University of Alfenas, Minas Gerais, Brazil. $\$ hmjunior2000@yahoo.com (D) https://orcid.org/0000-0001-9691-2802

$\begin{array}{ccc}\text { Recebido em } & \text { Aceito em } & \text { Publicado em } \\ 07 / 08 / 2020 & 25 / 11 / 2020 & 31 / 12 / 2020\end{array}$


(http://www.vatican.va/content/francesco/en/encyclicals/documents/papa-

francesco_20150524_enciclica-laudato-si.html).

At different times and situations, the Pontiff has spoken out about local and global problems and challenges. In a letter of Science, for example, shows that the leader of the world's largest Christian faith might succeed in doing something that many experts have failed to achieve. ${ }^{1}$ In this period of the COVID-19 pandemic, with expressive and sad numbers that we have observed the daily increase, as of August 5, 2020, there are already 18.3 million confirmed cases and 696,147 deaths (https://who.sprinklr.com), it's been no different.Pope Francis, on March $28^{\text {th }}, 2020$, wrote this in a letter to Roberto Andrés Gallardo, President of the Pan-American Committee of Judges for Social Rights, welcoming the decisions of those governments that prioritized health over the economy in times of COVID-19, and the Pope continues, some governments have taken exemplary measures with well-defined priorities to defend the population. He even said that the governments that face the crisis in this way show the priority of their decisions: people first (https://www.vaticannews.va/en.html).

In an Editorial, COVID-19: learning from experience, highlights alongside the deep distress felt as many countries experience a peak in cases or brace for it, there is also a growing understanding about the importance of the collective and community. It is imperative that the global community takes advantage of this spirit of cooperation to avoid repeating this error in more vulnerable countries. ${ }^{2}$ This Editorial goes very far in line with the Document published by the Pontifical Academy of Sciences (http://www.pas.va/content/accademia/en/events/2020/coronavirus.html).

The text highlights that international organisations like WHO and UNICEF, but also academies of sciences, need to be supported in their communication efforts so that their scientific evidence-based information can rise above the cacophony of unproven assumptions spreading all over the world. A lesson the virus is teaching us is that freedom cannot be enjoyed without responsibility and solidarity. Freedom divorced from solidarity breeds pure and destructive egoism. Nobody can succeed alone. The COVID-19 pandemic is an opportunity to become more conscious of how important good relationships are in our lives. And the document ends by saying that today's paradox is that we realize that each person needs to cooperate with other people at the exact same time as it becomes necessary to isolate ourselves from everyone else for health reasons. However, this paradox is only apparent since the act of staying at home is an act of profound solidarity. It is to "love your 
neighbor as yourself". The lesson the pandemic teaches us is that, without solidarity, freedom and equality are just empty words (Pope Francis).

On March $27^{\text {th }}$ of 2020, in his homily of the blessing Urbi et Orbi, the Pope said that the storm unmasks our vulnerability and exposes the false and superfluous security with which we build our programs, our projects, our habits and priorities. It shows us how we leave asleep and abandoned what nourishes, sustains and strengthens our life and our community. The storm exposes all the purposes of "packing" and forgetting what fed the souls of our people; all attempts to anesthetize with apparently "saving" habits, unable to appeal to our roots and evoke the memory of our elderly, thus depriving us of the immunity necessary to face adversity. With the storm, the make-up of the stereotypes with which we mask our "self", always concerned with our own image, fell; and it was discovered, once again, that (blessed) common belonging from which we cannot escape: belonging as brothers (https://www.time24.news/t24/2020/03/full-text-of-pope-francis-homily-this-march-

27.html).Thus, we must always remember the words of Pope Francis, never been such a clear need for science to protect the planet (https://www.washingtonpost.com/news/energyenvironment/wp/2016/11/29/pope-francis-urges-world-leaders-not-to-delay-climatechange-efforts/).

\section{ACKNOWLEDGMENT}

The Minas Gerais State Research Foundation (FAPEMIG, Minas Gerais, Brazil), the National Council for Scientific and Technological Development (CNPq, Brazil), and the Coordination of Training of Higher Education Graduate Foundation (CAPES, Brasilia, Brazil).

\section{REFERENCES}

1 LAVELLE, M. Moveable feast. Science. 2015 Nov 13; 350 (6262): 760-3. DOI: 10.1126/science.350.6262.760.

2 USHER, A.D. COVID-19: Learning from experience. The Lancet 395, 1024, 2020. 
